\title{
Reflecting Teacher Figure Through Personality
}

\author{
Aida Ambarawati* \\ *Postgraduate Pedagogics, Universitas Pendidikan Indonesia, Bandung, Indonesia \\ Pengiriman: Mei 2020; Diterima Juli 2020: Publikasi: Juli 2020
}

\begin{abstract}
Education is not only about transfer of knowledge, it is also an attempt to shape one's personality of characteristics. Personality is a factor that has an important role in the success of teaching and learning conducted by teachers, related to ascpect cognitive, affective, and psychomotor toward their students, so the ideal teacher is needed not only in terms of intellectuals, but also in personality. The research conducted is using literatur study with data obtained from literature review. This article aims to describe and analyze how to become the figure of an ideal teacher with a personality that can be a role model for all levels of society, especially students. Armed with the ideal personality competence, teacher can be more flexible in helping the formation of the personality of their students, so that it can help to achieve one of the aims educational, it is to prepare characterized human resources (HR).
\end{abstract}

Keywords: Teacher Figure, Personality, teachers competence, teachers personality.

*Penulis Korespondensi:

Alamat surel: Aida@upi.edu 


\section{INTRODUCTION}

Current development has such a huge impact on human life, one of these changes will have an impact on the quality of education. In improving the quality of education, there is a very important component in education named teachers or educators who have a major role in education. One important external factor in formal education is the teacher, because the teacher is directly involved in learning activities, the formatin and development of intellectual and student personality (Syaidah et al., 2018: 186). Other than that, the existences of an ideal or competent teacher thet it can help ti improve learning outcomes that lead to the aims of national education as written in Nurihsan (2016: 12) that educational aims in Indonesia listed in the Republic of Indonesia law number 20 of 2003 chapter I, article I paragraph I:

National education aims to develop the potential of students to become human beings who believe and fear God almighty, have a noble character, healthy, knowledgeable, capable, creative, independent, and become democratic and responsible citizens.

The main task of the teachers are to teach and educate, keep improving the competence to face advances in education. Teachers are positions or professions that require special skills as teachers. This work is not easy, cannot be done by just anyone without professional expertise (Nurhaidah \& Musa, 2016: 9). Therefore, it is the initial providion, there are four teacher competencies in the minister of national education regulation number 15 of 2007, they are: pedagogics competence, personality competence, social competence, and professional competence. Teachers are expected to become role models for students with these four competencies.
Based on the aims of nation education, there is an aim to shape and guide students to become human beings with characteristics (personality). Related to that, teachers are also needed to have mature personalities. Every teacher is required to have sufficient personality competencies, even these competencies will be underline or become the foundation for other competencies (Mulyasa, 2008: 117).

The charateristics of the personality teacher has, can describe the competence and authority of the teacher at the school environment. The teacher and also the community environment. The teacher personality will determine if the teacher is a good educator and coach or not the students perspective (Nursyamsi, 2014: 40). Because of the personality possessed by the teacher, students can see directly and imitate it which can affect behavior, learning success, and other aspects related to students. As written by (Shabani \& Ghasemian, 2017: 15 ) is that teacher personality can have affect on the learners learning because the learners are dependent on their teachers in some aspect.

That is why, the teacher is the main factor in education that must have good characters to be imitated by the students and people around. We can call them ideal teachers. Ideal teachers are teachers who can be a role model and always provide an example for their students (Oktradiksa, 2012: 244).

\section{LITERATUR REVIEW}

Being a teacher is not an easy job. A teacher must master at least four competencies. Those competencies are things that can support the success of the learning of students to achieve national education aims. As stated by (Musfah, 2011: 27) that competence is a collection of 
knowledge, behavior, learning, and education aims. Charles (in Mulyasa, 2008: 25) argued that competence as rational performance which satisfactorily meets the objective to a desired condition.

General competence related to cognitive, affective, and psychomotor owned by individuals. Competency is generally defined as the integration of knowledge, skills, an attitudes (Stoof et al, Tigelaart et al, Zhu \& Wang, 2014: 299). It can be concluded that competence, in general, is a character and holistic ability possessed by a person who is supporting the success of a job's goals.

One of the basic capital to form and prepare human resources as the successor to the nation is the teacher that has an ideal personality. The personality of a teacher is a fulcrum as a balance between knowledge about education and skills, carrying out the professional as an educator especially in learning (Surya, 2014: 254). Apart from being the fulcrum the teachers personality according to Suharsaputra (2013: 36) is,

Teacher personality can be interpreted as all aspects of the inherent and dynamics aspects of the teacher that are

The basic and influence the way of thinking, feeling, and behaving in carrying out their roles and duties as educators, both in their interactions with students, other teacher colleagues, staff leaders, and educational organizations school.

Behavior or actions taken with the school environment or outside the school environment is a picture of the person's personality. Before teaching or internalizing character toward students, a teacher must show the noble character of the teacher first (Wibowo \& Hamrin, 2012: 47). Ideally, being a teacher must have a good personality, so the teacher must begin to change their behavior to become an example for their students, and change the learning paradigm from merely a theory to a real practice as one of the ways of farming the character of a personality.

More than that, when talking about a teacher, it is not just how to have an ideal personality but more than that, the teacher must be able to position himself with other teachers and the surrounding community, so that personality in this case becomes an important ability or faculty. Confirmed by, e.g., Sikula (In (Decker \& RimmKaufman, 2007: 47)

Personality. Teaching requires not only the ability to tach lessons, but also understanding of the rules and routines of the school culture, the ability to collaborate with other education professionals, and an awareness of the communities in which one teaches.

\section{TEACHER'S PERSONALITY COMPETENCE}

The teachers are one person who has an important role in farming personalities that have an impact on changes in student behavior. (Musfah, 2011: 43) the essence of learning is behavior change, the teacher will be able to change the behavior of students if he or she becomes a good person. To form one personality can be influenced by the environment, as well as for students who always spend most of their time in a day at school, where they will see, imitate, and copy the teacher's behavior that they often see.

Husna (2015: 21) teacher personality competence is competence related to the teacher's personal behavior which must have noble values them it will be seen in daily behavior. This personality competence has a very big impact on the personal development of the students. As Aedy (2009: 82) said, and the most amazing thing is a person's personality will change by training implemented by educators of teachers at school. In this case, paradigm a teacher must be able to carry out 
learning which is also used a means of establishing for students. To form the personality characteristics of students is one of the responsibilities of a teacher.

A teacher plays a very important role in the overall learning process at school, for example in dealing with problems that his students have. There are many psychological problems faced by students. There are also many interests, abilities, motivations, and needs. All of them require the guidance of teachers who can act as tutors, instructors, and can help students to be able to help themselves (Asmara, 2015: 21). Therefore, teachers are required to have a strong personality, so they can help students in making the right decisions and help the students to reach their maturity.

Many problems will arise in education, one of them is because by the teacher who has not good or an ideal personality. The teacher must change his selfconcept. Based on the results of research conducted by (Rangkuti \& Azis, 2014: 77) with sample taken in the study were elementary school, junior high school of East Jakarta, that produces data related to the personality of teachers that are liked by students and effective teachers consisting of noble, patient, respectful, encouragement to learn and fun. In addition, research conducted by (Norahmi, 2017:89) the subject of the research were of English Education Study Program, University of Palangka Raya, that students want teachers who have personality to be objective, creative, consistent, tolerant, discipline, smart, up-to-date, solutive, broadminded, open-minded, communicative, kind-hearted, responsible, friendly, polite and wise. Based on the constitution in government regulation number 29 of 2005 concerning national educational standards article 28 paragraph 2 , personality competence is a personal ability that is 1 ) steady, 2) stable, 3) mature, 4) wise and prudent, 5) authoritative, 6) noble character, 7) being a role model for students and the community, 8) evaluating his performance, and 9) keep developing his ability. These indicators serve as a guide to becoming a professional or ideal teacher who has a personality. The teacher's personality is a philosophy of life and values develop a teacher is located (Asmara, 2015: 22).

And then, most of the learnners are teacher'soriented and believe that their instructor is the sole authority in class and they may obey the teacher's sentence or rules by observing teacher's behavior (Shabani \& Ghasemian, 2017: 6). The teacher's personality that arises fro his daily behavior and actions will describe his-self and can influence student's behavior. More broadly, the personality of educators or teachers in question regarding all actions including how they make decisions and how their attitudes in dealing with every problem they encounter (Sstrawan, In Warsah \& Uyun, 2019: 64). So it is not just about acring, but how to behave too.

\section{THE TEACHER PERSONALITY THAT IS STEADY AND STABLE}

The meaning of steady according to Sussana (2014: 385) a steady personality means that the person has an unshakeable personality (remains firm and strong). One of the factors causing various problems in education is because the teacher's personality is lessstable. One of the impacts is the teacher who acts improperly. So that it can hamper the learning process. A good teacher should be cooperative, willing to compromise mild-mannered and benevolent with faith in mankind (Göncz, 2017: 86). 
As a teacher, we must have a commitment and steady establishment of his task for good investigations. The teacher's commitment is not shaken on things that are not commendable, have a high discipline ethic, committed to what has become his responsibility, abide by the laws and regulations, guide, accompany students, be proud being a teacher and one of the most important is being able to control his emotions. The stability and emotional maturity $f$ the teacher will develop together with his experience, as long as he or she wants to utilize the experience (Sussana, 2014: 387). In other words, a teacher should learn from his experiences for stable emotion facing people around especially his students.

The teacher should be a sensitive person who recognizes and understand the needs of the child, the adult, and the community. to be understanding, he must be emotionally stable, able to-project himself the situation of those around him, he must be unselfish (Dugan, 2015: 335).

It is clear, that to develop a stable personality, a tteacher must also begin to learn sensitive, to the development and needs of others by not discriminating with who and for whom the teacher works. With a sensitive and being understanding characteristic, it will help the teacher to have emotinal stability.

\section{THE TEACHER MATURE PERSONALITY}

A teacher should describe the mature attitude in guiding and fostering students to achieve success. The teacher who is responsible for the task is the teacher who has learned as a mature. Mature attitude personality, according to (Wibowo \& Hamrin, 2012: 115) is,

Showing independence in acting as a leader, it's characteristics are: a) carry out the task independently, b) make decisions, c) assess his self. To have a work ethic as educators, its characteristics are: a) work hard, carry out their duties responsibly, c) develop themselves continuously as educators.
But also (Arisman an et al., 2018: 423) bring the maturity of the teacher is reflected in the stability of his emotions. To become a mature teacher not only helps shape the personality of the students. More than it, teachers must be able to accept criticism and suggestions from the surrounding environment, be independent, and must be able to develop their abilities in solving problems that arise in education, especially their students. The mature personality of a teacher must also show openness in thinking and prioritizing many people, especially students who make them feel protected.

\section{THE TEACHER WISE PERSONALITY}

The meaning of wise is to always use reason, a wise person is a person who always uses his mind (Sudewo, 2011: 183). When something happens that is not wanted and not expected, the teacher must be wise, use his mind in dealing with problems that arise, not on considerations his emotions or lust. It's means, a teacher sometimes faces situations that require her or him to make a decision. In making that decision, the teacher must consider many things. So that the decision wisely in accordance with the function. According to Surya (2014: 244) this wisdom is a form of practical intelligence that is characterized by a balance between intrapersonal interest (within oneself) and interpersonal interest (outside personal). Therefore, in taking and making decisions, a teacher must be wise, act rationally with benefits to the environment of the school and community with away from his personal interest.

One application of a wise person is patience and moral in acting. According to (Wibowo \& Hamrin, 2012: 116) about the personality of wise teachers are,

1) shows actions based on the benefit of students, 2) acts on the basis of school benefits, 3) acts on the basis of community benefits, 4) shows openness in 
thinking and acting with characteristics of accepting criticism and suggestions for improvement and placing themselves proportionately.

Based on this theory, as a teacher who has a wise person there is behaving and taking action must be based on the benefits for various parties and show openness in acting and thinking.

\section{AUTHORITATIVE TEACHER PERSONALITY}

With the personality of the teacher who has a steady authority it can affect the perspective of students. The meaning of authority, is not to force his self and dictate. As is Manurung (2008: 511) authoritative teacher is a teacher who can make his students affected by his words, his teaching, obedient to his achieve, and able to become a magnet for his students. So that his students will be amazed and diligently listen to his teaching. To make the students obey their teacher, the teacher must have a quality personality. (Pratiwi, 2018: 45) authority a trait that can influence others through charisma and performance, so that respect is created. As according to (RAIČEVIĆ an et al, 2017: 239) the teachers must show by example that she or he respects the dignity of each students, so that they can learn to respect and others mature in their environment. The teacher must also give examples in advance to respect each of his students, so that students can learn to respect people who are older than them.

There are elements that make up authority, according to Surya (2014: 329) is a) having advantages, b) having confidence, c) be right in making decisions, and d) be the responsibility for decisions that have been decided. These elements will form behavior that can be respected and can change students view of point the teachers. In an education, to form the personality of learners who have characteristics must begin with the personality of the teacher who has high authority.

THE TEACHER PERSONALITY THAT IS A NOBLE CHARACTER

One of the aims of national education is to form students who have good morals. The word "morals" comes from Arabic which has become Indonesia and comes from the word "khuluq" which means behavior or character (Ahmad, 2002: 364). In short, this noble characters is related to behavior o shape these character, the teacher must have good intentions first, faith, and devotion that obeys religious norms and can be a good example. Noble morals are born because of humans and can be the belief in an almighty God (Bernawi \& Arifin, 2012: 159). A teacher should have a noble personality, because the teacher has the main role to strengthen positive energy and shape the quality of the learner's personality. So, as to achieve noble and Godly character.

To create students with noble character is not easy, the teacher must be able to be a good advisor for the students. Mulyasa (2008:129) stated the teacher must have a noble character because he or she is an advisor for students and even for parents. Even though they do not have special training as advisors that are heard by students, the teachers must have morals good a nobel, accompanied by authority, so that it can be emulated.

\section{THE TEACHER PERSONALITY AS A ROLE MODEL FOR STUDENTS AND THE COMMUNITY}

Basically, humans like to imitate. To be a good role model, ideally the teacher must always be aware of what he or she is doing. Having good knowledge is not enough to show that teacher is able to be a role model, this must be supported by real behavior, which can be 
seen and observed by others (Lestari \& Purwanti, 2018: 205). The teacher is one of the figures used as a role model by students, especially at the school environment. Because the personality shown by the teacher can have an indirect effect on the morality of the students.

There are several things that need to be considered shaping the role model figure for students according to (Mulyasa, 2008: 127), they are: a) basic attitudes, b) speaking and speaking style, c) work habits, d) attitudes toward, experience, and mistakes, e) clothing, f) human relations, g) thought processes, h) neurotic behavior, i) tastes, j) decisions, k) health, and l) general lifestyle. The elements above are sometimes used as an assessment by students because these elements are a picture of the teacher in carrying out their daily tasks. What is done and used by the teacher, it is very likely to be emulated by their students. Because an example shows a person's quality, then one example will create another example. As from the results of research conducted by (Karso, 2019) in the 4 elementary school of Rimau Island, the study stated that in general the role models of teachers were seen in honest, disciplined, cooperative and moral personalities.

With various shortcomings that are owned by a teacher as a normal human being, the teacher must be an example for students and the community. Roochman \& Gunawan (in Arisman an et al., 2018: 426) asserted that we realize it or not, one's self-awareness will affect the surrounding environment, the exemplary that is given will provide a fairly large image of the community. Therefore, the teacher must always try to control themselves and improve themselves continuously be able to become a role model figure.

\section{THE TEACHER PERSONALITY THAT EVALUATES HIS OWN PERFORMANCE}

As a teacher, must have the awareness to understand, to correct, and to know himself. Starting from an experience that can be obtained beforehand will be a further evaluation. According to (Musfah, 2011: 48) the purpose of evaluating one's own performance is to improve the learning process in the future. And Danim's (2011: 158) self-evaluation is the teacher's personal attempt to find a picture of his own performance and situation through self-assessment and analysis relating to strengths, weaknesses, opportunities challenges, obstacles, and even threats to this existences as a teacher.

The purpose of the existence of a self-evaluation after learning is to know and reflect on the extent to which the result of the learning process that has been done with the quality of teaching that can be seen from the response or feedback of students. The response or feedback can be used by the teacher as self-evaluation material ti improve his self. In other words, to find out about the performance that has been done. Or in other words, is teacher evaluation, teacher evaluation is a formal and systematic process of examining teacher performance (Stronge, In Akram \& Zepeda, 2015:134). By evaluating themselves or teacher's, the teachers will know and find out the extent to which himself performance has been achieved, both related to himself or students as feedback from self-evaluation.

The personality of each teacher is different, has advantages and disadvantages of each. Therefore, the the teacher must be able to evaluate himself in order to place himself correctly. There are several goals of selfevaluation according to (Danim, 2011: 15): 
a). Compile your personal profile, abilities, skills, competencies, and self-performance, b). As a precondition to plan and carry out self-improvement actions continuously, c). Internal quality assurance by himself, d). Providing honest and open information about personal strengths and weaknesses to students colleagues and others, and e). Personal preparation to ask the third party in order to determine the priorities of the teacher's professional development program.

Knowing your self is the best way. No matter what grade level or what subject you want to teach, it is important to find out how much you know about yourself (Kim \& Kellough, 1983: 6). Form some of the objectives of self-evaluation, in the end will form self-confidence in the teacher.

\section{THE TEACHER PERSONALITY WHO DEVELOPS HIMSELF CONTINUOUSLY}

Self-development is taking one's own potential (Danim, 2011: 188). Self-improvement is an element that must always be done by teacher's because orf rapid development of technology and information, teachers must be able to adjust their ability to continue to pursue changes that occur in this world. Therefore, teachers must always develop themselves of it. The more developed the method used, the more creative and innovative learning media. That is only a small part of the changes that occur. Efficient teachers should be open to novelty, curious and creative, and have a well-developed vocabulary (Göncz, 2017: 86). However, a teacher must always develop himself and be more open to new things and related to the needs of the times as a provision for a future that has values.

If you don't develop your self as a teacher, you will experience a set back in your knowledge and competence as a teacher. To improve the quality of oneself for the teacher, (Danim, 2011:196) said:
Do not be afraid of making mistakes, change lives by changing something that is done every day, formulate realistic expectations for self-improvement, change and continual improvement, motivational prime moves, don't always expect results quickly, focus, and allocated $80 \%$ of work time according to your ability.

Self-development is not ony related to selfdevelopment by adjusting to the times, but as selfimprovement. Hasibuan (2014: 298) Self-development is closely related to self-improvement, even connotatively it is possible to have the same meaning, begins with an introduction to who you rally are. In doing personal development, it is not easy. Must be done continuously. The first step is recognizing oneself. By recognizing oneself, a teacher will be able to understand the competence of those possessed and those that ais not yet possessed, so that they can develop themselves appropriately and produce something useful. In the process of recognizing oneself, a person will have been in a position where that person gives up and dissolves in the circumstances. To get out of a situation that is not supportive, the teacher should have the courage to bring himself out of the situation. (Danim, 2011: 201) do the action to break your self to make a surprise, actualize the plan into implementation translate the subconscious mind to produce great actions for the sake of achievement in education and learning.

From the various descriptions and analyze above, there are also result of research that has been carried out out one of them by Khan et al (2016: 74-79) with the purpose to conducted to students in the disciplines of sport and physical education in university-level consisting of 418 students $30 \%$ from each of the universities in Pakistan universities. From the result of 
research that has been done, it was found that the teacher's personality is one of the main keys that gives an influence and impact on student's academics.

In addition, Sanrego (2015) conducted a study at MAN 1 Konawe Selatan to 49 student's who showed that the $\mathrm{t}$-test result found that $\mathrm{t}$-test values were greater than $\mathrm{t}$-table $(4,043>2,012)$, it is meaning at MAN 1 Konawe Selatan. It is clear, that the personality of a teacher will affect students holistically.

From what was revealed by (Sarjana \& Khayati, 2017: 382) the personality of the teacher has a direct and cumulative influence on the behavior of students. These influential behaviors include study habits, discipline, learning desires, and learning motivation. In the end, the teacher's personality will not only have an impact and help in shaping the personality of the students. More than that it will affect the quality of student learning as well. Because, personality is somehing that is complex and dynamic that can affect the behavior of others. Because it is according in (L. E. Kim et al., 2019: 164) personality describes the unique psychological qualities that influence individuals' behaviors, thoughts, and feelings across situations and times. Another thing, although each teacher has a different way of teaching and it is own uniqueness, but iit all must be balanced with an ideal personality.

\section{CONCLUSION}

The teacher who is a device of the educational activator, will spearhead the success of his students. One of that affects the quality of a teacher is his personality. The personality will have an impact on the success of their students. To be a role model for students is not easy. The teacher must recognize himself first, evaluate himself, and be a role model for himself first. One of the most important as the formation of the personality of students is that it must be implemented first, so that the theories are balanced with their actions. This is why the teachers must recognize themselves first, it is all done to achieve a personality that is steady, stable, mature, wise, authoritative, noble, and can be a role model. In addition, the teacher must also be given a continuous education and training facilitated by the school or government, then this will improve the competencies of the teachers, especially personality competencies.

\section{REFERENCES}

Aedy, Hasan. (2009). Karya Agung Sang Guru Sejati. Bandung: Alfabeta.

Akram, Muhammad., \& Zepeda, Sally. J. (2015). Development and Validation of a Teacher Self-assessment Instrument. Research and Reflections in Education, 9(2), 134-148.

Amara, Husna. (2015). Profesi Kependidikan. Bandung: Alfabeta.

Arisman an, Getteng, A. R., \& Nuryamin, N. (2018). Pengaruh Kompetensi Kepribadian Guru Terhadap Motivasi Belajar Peserta Didik Mtsn 2 Bone Kabupaten Bone. Jurnal Diskursus Islam, 6(3), 418-443.

Barnawi \& Arifin, M. (2012). Etika dan Profesi Kependidikan. Yogyakarta: Ar-Ruzz Media.

Danim, Sudarwan. (2011). Pengembangan Profesi Guru: Dari Pra-Jabatan, Induksi, ke Professional Madani. Jakarta: Kencana Prenada Media Group.

Decker, Lauren. E., \& Rimm-Kaufman, S. E. (2007). Personality Characteristics and Teacher Beliefs among Pre-Service Teachers. Teacher Education Quarterly, 35(2), 45-64.

Dugan, Ruth. R. (2015). Personality and the Effective Teacher. The Journal of Teacher Education, 12 (3), 335-337.

Göncz, L. (2017). Teacher personality: a review of psychological research and guidelines for a 
more comprehensive theory in educational psychology. Open Review of Educational Research, 4(1), 75-95.

Hasibuan, M. (2014). Urgensi Dalam Pengembangan Diri Menjadi Agen Pembelajar Sejati). Analytica Islamica IAIN-SU, 3(2), 296-313.

Karso. (2019). Keteladanan Guru dalam Proses Pendidikan di Sekolah. Prosiding Seminar Nasional Pendidikan Program Pascasarjana Universitas PGRI Palembang, 12 Januari 2019, 2, 382-397.

Kim, Eugene. C., \& Kellough, Richard. D. (1983). A Resource Guide for Secondary School Teaching $3^{\wedge} r d$ Eddition. Macmillan Publishing CO., Inc.

Kim, Lisa. E., Jörg, Verena., \& Klassen, Robert. M. (2019). A Meta-Analysis of the Effects of Teacher Personality on Teacher Effectiveness and Burnout. Educational Psychology Review, $31(1)$, 163-195. https://doi.org/10.1007/s10648-018-9458-2.

Lestari, Y. A., \& Purwanti, M. (2018). Hubungan Kompetensi Pedagogik, Profesional, Sosial, dan Kepribadian Pada Guru Sekolah NonFormal X. Jurnal Kependidikan, 2 (1), 197208.

Mulyasa, E. (2008). Standar Kompetensi dan Sertifikasi Guru. Bandung: Remaja Rosdakarya.

Musfah, J. (2011). Peningkatan Kompetensi Guru: Melalui Pelatihan dan Sumber Belajar Teori dan Praktik. Jakarta: Kencana Prenada Media Group.

Norahmi, M. (2017). Journal on English as a foreign Language 21 st century teachers: The students' perspectives. 7(1), 77-96.

Nurhaidah, \& Musa, m. I. (2016). Pengembangan Kompetensi Guru Terhadap Pelaksanaan Tugas Dalam Mewujudkan Tenaga Guru Yang Profesional. Jurnal Pesona Dasar, 2(4), 8-27.

Nurihsan, A. J. (2016). Membangun Peradaban Melalui Pendidikan dan Bimbingan. Bandung: Refika Aditama.
Nursyamsi, N. (2014). Pengembangan Kepribadian Guru. Al-Ta'Lim, 21(1), 32.

Oktradiksa, A. (2012). Pengembangan Kualitas Kepribadian Guru Pengembangan Kualitas Kepribadian Guru. Jurnal Pendidikan Islam, 6 (2), 231-248.

Rangkuti, A. A., \& Azis, H. A. (2014). Gambaran Karakteristik Kepribadian Dan Nilai Guru Efektif Yang Disukai Berdasarkan Perspektif Siswa Sekolah Negeri Di Jakarta Timur. JPPP - Jurnal Penelitian Dan Pengukuran Psikologi, 3(2), 74-79.

Raičevic, Jelena., Nikolič Sanja., Lipovac, Vlasta., Saračevic, Muzafer. 2017. Teachers and Social learnin As A Factor Of Modern Educational Competencies. Bulgarian Journal of Science and Education Policy. 11 (2): 233-245.

Sanrego. 2015. Pengaruh Kepribadian Guru Terhadap Perilaku Siswa MAN 1 Konawe Selatan. Skripsi. Institut Agama Islam Negeri (IAIN). Kendari: Tidak diterbitkan.

Sarjana, S., \& Khayati, N. (2017). Pengaruh Etika, Perilaku, Dan Kepribadian Terhadap Integritas Guru. Jurnal Pendidikan Dan Kebudayaan, 1(3), 379.

Shabani, K., \& Ghasemian, A. (2017). Teacher's personality type and techniques of teaching pronunciation. Cogent Education, 4(1).

Sudewo, E. (2011). Character Building. Jakarta: Republika Penerbit.

Suharsaputra, U. (2013). Menjadi Guru Berkarakter. Bandung: Refika Aditama.

Surya, Mohamad. (2014). Psikologi Guru Konsep dan Aplikasi. Bandung: Alfabeta.

Sussana. (2014). Kepribadian guru PAI dan Tantangan Globalisasi. Jurnal Mudarrisuna, 4, 376-396.

Syaidah, Umu., Suyadi, Bambang., \& Ani, Hety. M. (2018). Pengaruh Kompetensi Guru Terhadap Hasil Belajar Ekonomi Di Sma Negeri Rambipuji Tahun Ajaran 2017/2018. Jurnal Pendidikan Ekonomi: Jurnal Ilmiah Ilmu Pendidikan, Ilmu Ekonomi Dan Ilmu Sosial, 
12(2), 185.

Warsah, I., \& Uyun, M. (2019). Kepribadian Pendidik: Telaah Psikologi Islami. Psikis : Jurnal Psikologi Islami, 5(1), 62-73.

Wibowo, A., \& Hamrin. (2012). Menjadi Guru Berkarakter. Yogyakarta: Pustaka Pelajar.

Zhu, C., \& Wang, D. (2014). Key competencies and characteristics for innovative teaching among secondary school teachers: A mixed-methods research. Asia Pacific Education Review, 15(2), 299-311. 